\title{
Prakritic Aspects Appearing in the Chih Ch'ên's Translation (I)
}

\section{Asao Iwamatsu}

It is said, and is probably true, that Buddhism was first introduced into China about the beginning of the Christian era or, at the latest, by the middle of the 1st century $\mathrm{AD}$. But whatever the legends may say, the history of translation of the Canon began almost over a century later. There is evidence to show that the first authentic translator was An Shih Kao 安世高, who is said to have come to China ca. $146 \mathrm{AD}$. and engaged in translation and propagation. But his works were mostly from the Agamas and Abhidharmas of so-called Hinayana Buddhism. Therefore, the title of the first translator of Mahayana texts should be ascribed to Chih Ch'ên 支識 (or Chih Lou Chia Ch'ên 支婁迦誐) who were the next to arrive in China nearly 20 years later. In $C h^{\varsigma} u S a n$ Tsang Chi Chi 出三蔵記集, the oldest Catalogue of Buddhist works extant, 14 works are registered as Ch'ên's own, and most of them, so far as is known from both sutra-titles and commentaries attached to them, belong to Mahayana Buddhism. To our regret nearly one-third of them are lost, and among these several are of unknown content.

For some reason Ch'ên prefered transliteration to translation not only in proper names but also in some technical terms - in this regard his work differs from that of Chih $\mathrm{Ch}^{\text {'ien }}$ 支謙, his “second generation successor", who dared to translate into Chinese even such proper names as, for example, Subhūti, Shan Yeh 善業, and Mañjuśrĩ, Ching Shou 敬首. Fortunately, of Ch'ên's surviving works two can still be compared with equivalent Sanskrit texts. One of these, Tao Hang Pan Jo Ching 道行般若経 (Taisho, no. 224) corresponds to Astasāhasrikā (Mitra. Calcatta, 1888); and the other, Fo Shuo. I Jih Mo Ni Pao Ching 仏説遺日摩尼宝経 (Taisho, no. 350), corresponds to Kāśyapaparivarta (Staël-Holstein. Shanghai, 1926). Though the latter is not so lengthy, the former 
is quite voluminous. It consists of ten fasciculi (Chüan 巻), and contains nearly 160 transliterated words; whereas I Jih Mo Ni Pao Ching consists of but one fasciculus, and contains at most 40 transliterated words, many of which agree with those of Tao Hang Pan Jo Ching. By way of comparisonand, when this is insufficient, investigation of other sources-most transliterated words can be matched with their Sanskrit equivalents; though, of course, exceptions are not rare, especially in the case of proper names.

Of equal interest to the scholar concerned with the translation of the Buddhist Canon or its older forms, is the question regarding the type of language in which the original text was written; in other words whether the text was written in Sanskrit or not, and when not in Sanskrit, in what type of Prakrit. As for the two Chinese texts mentioned above, so far as is known from the transliterated words which have been matched with Sanskrit equivalents, the original language was apparantly not Sanskrit. In many respects the transliterated words show Prakritic characteristics, some of which, however, differ both from those of Pali, as well as from those of such types of Prakrit as so-called Middle and Late Prakrit. Here we are reminded of the peculiar Prakrit, the so called Gāndhārī or North-West Prakrit used in the N-W. region of ancient India and once in the southern district of Chinese Turkestan, also. If indeed Ch'ên's native country, Ta Yüeh Chih 大月支 (or 大月氏), was actually Kushana Empire, it is possible that he spoke the Gāndhārī language and that the text itself was written in it. In fact the original language and Gāndhārī show identical characteristics in some respects; thus it can at least be positively affirmed that there was a close relationship between them. Nevertheless we should be most prudent in considering whether they were the same, or still more so in presuming that some primitive Mahayana texts were first composed in Gāndhārī in the N-W. region; for in some details these two languages do not seem to coincide completely.

In any case I will show in this paper some Prakritic aspects which actually seem to appear in those transliterated words. Of course, since the pronunciation of Chinese characters in this period is still not sufficiently clarified, these conclusions are provisional and may be modified subject to further investigation. 


\section{Prakritic Aspects (A. Iwamatsu)}

As it is much more difficult to reach any conclusion regarding vowels, I would like to restrict our present investigation to consonants. Initial consonants, we may say, generally remain unchanged; but medial consonants do not obey any uniform rule. As for consonant clusters, although most of them seem to be assimilated or divided by svarabhakti, it is most likely that in very few cases they are kept unchanged. Here I shall begin with the topic of single consonants, especially sibilants.

[Sibilants] In Gāndhārī the three sibilants $s \underline{s} s$ are said to be preserved. Such is the case, probably, in the above cited transliterations, though examples of the Skt. $s$ are not frequent enough to definitely assert its preservation.

We may generalize that both $\dot{\mathbf{s}}$ and $\mathbf{s}$, whether initial or medial, undergo no change. For, without a single exception in the case of initials, and only a few exceptions in the case of medials, $s$ is transliterated using characters with the Ancient Shên 番 initial belonging to Division III (=s $\left.s^{-}\right)$such as $S h \hat{e}$ 舎, $S h i h$ 釈, Shih 户 and Shou 首; while $s$ is transliterated with those of Hsin 心 initial ( $=s-)$ such as $S a$ 薩, $S a n$ 三, $S \hat{e}$ 塞, Sêng 僧, Hsü 須 and $S s \ddot{u}$ 斯; and no confusion is found between them. In two instances $s$ is transliterated using characters with the $Y \ddot{u}$ 喻 initial belonging to Division IV $(=j-$ ), such as $I$ 翼 and Yeh 耶 (or its variant reading Hsieh 邪 in another editon); and in but one instance is $s$ also transliterated using character with this $Y \ddot{u}$ 覦 initial, i. e., $I$ 夷. As for these exceptions, it is possible that they indicate the phonological change of $s$ or $s$ into $y$. There are some other exceptions which seemingly indicate mutual changes within the sibilant group itself: e. g., $s>s, s>s, s>s$ and $s>z$. But we can reach a definite conclusion only after further investigation.

Regarding s, its appearance is restricted to only two words. One is Tuṣita and the other is kașayya. To the former $s(-i t a)$ is applied the character $S h u$ 術 which belongs to the $C h^{\prime}$ uang 爿木 initial of Division $\operatorname{III}\left(=d z^{\prime}-\right)$. To the latter $s(-\bar{a} y a)$ is applied the character Sha 裟 which belongs to the Shên 審 initial of Division II $(=s-)$. The initial of $S h u$ 術 is voiced and not of Division II; thus in some respects it does not seem to resemble the Skt. $s$ (-ita) strictly. Regarding the character Sha 裟, as it does not appear in Shuo Wen Chieh Tzü 説文解 字 and was probably unknown in the Archaic period, it is likely that it was 
a newly created character designed to transliterate the or ig in a l (ka-)șāya. It consists of the phonetic segment $S h a$ 沙 and the semantic segment $I$ 衣, and in Ancient Rime Dictionaries (Yün Shu 韻書) its initial is no doubt that of Shên 審 of Division II. Consequently it is possible to suppose the maintainance of the original sound in the case of $s$ as well as in the cases of $\dot{s}$ and $s$. For one thing, there is a distinct difference between the initials of applied characters corresponding to Skt. $s$ and those regularly corresponding to $s$ and $s$. Furthermore, we might suppose this case to be analogous to Gāndhārī, in which the three sibilants are preserved.

[Labials] In initial positions, including the latter component of compounds, p remains unchaged. In medial positions, however, it appears to be changed into $v$; except in the three cases of upassaka, upāsika and Atapa. In the first two cases $p$ is changed into voiced $b$; and in the last, $p$ remains unchanged.

Ph never appears. So far as is known from examples, b does not undergo any change either in initial or in medial positions.

The appearance of $\mathbf{b h}$ is most complicated. In bhikșu, the only instance of an initial $b h$, it is transliterated with the character $P i$ 比. As $P i$ 比 has two initials, Pang 幫 $(=p-)$ and Ping 並 $\left(=b^{-}\right)$, it is difficult to decide whether this $P i$ 比 indicates the original $p(-i)$ (i.e., the change $b h>p$ ), or else $b h$ (-i) (i.e., no change). Medial bh, while probably unchanged in Subhüti, seems to be changed into $h$ in 'subha and into $v$ in $a b h i^{\circ}$ and $\bar{a} b h a^{\circ}$.

$\mathbf{V}$ is uniformly unchanged. A single exception is found in the latter $v$ of Paranirmita-vaśavartin, in which ${ }^{\circ}$ vartin is transliterated with the characters $\mathrm{PaChih}$ 抜致. As $\mathrm{Pa}$ 抜 belongs to the Ping 並 initial ( $\left.=b^{6}-\right)$ group, this may indicate the change $v>b$. In other cases $v a$ is transliterated with the characters having the Hsia 匣 initial (including the Y $\ddot{u}$ 襌 initial of Division III) of Hou $K^{\prime} o u H u$ 合口呼 (=ru-), such as Huo 和, Yün 芸, Huan 桓, Huan 洹 and Yüeh 越. In the cases of $v i$ or $v e$, the character Wei 惟, which is of Yü 嗡 initial of Division IV of Hou $K^{\prime}$ ou Hu (=jw-), is used. These somewhat curious forms of trans literation are probably owing to the lack of labio-dental initials both in the Archaic and the Ancient periods. Phonologists of ancient Chinese assume that they separated from labials about the middle of the T'ang dynasty. 